\title{
CONFLICTS IN WATER TRANSFER FIROM IRRIGATION TO MUNICIPAL USE IN SEMIARID ENVIRONMENTS
}

By

C. B. Cluff

and

K. J. DeCuok

Water Resources Research Center University of Arizona

Paper presented at Telth Annual Cunference of the Anerican Water Resources Association, San Juan, Puerto Rico, Nov. 18-23, 1974. 


\section{CONFLICTS III WATER TRANSFER FROM IRRIGATION TO \\ WUHICIPAL USE IN SEMIARID ENVIRONMENTS}

C. B. Cluff and K. J. DeCook ${ }^{1}$

INTRODUCTION

Groundwater is the principal supply for irrigation and for rapidly increasing municipal water requirements in Arizona. As a result of this increasing demand water tables are declining at an ever increasing rate. Even with importation of water through the Central Arizona Project, transfer of water from agricultural to urban use is inevitable as the State continues to grow.

In the Phoenix area this transfer is occurring progressively without undue conflict. As the City expands, adjacent farmland is developed and water formerly applied to crops is used for clomestic purposes.

In the Tucson area, which at present is entirely dependent on yroundwater, outlying irrigated lands have been purchased and retired by the City and nearby mines to secure water rights. This forced retirement of farmland does present several conflicts which are discussed in this paper.

URBAIIZATION AHD WATER USE, PHOENIX REGION

The transfer of water from irrigation to municipal use in the Phoenix region has come about principally by the direct conversion of farmland to

IAssociate llydroloyists, Water Resources Research Center, The University of Arizona, Tucson, Arizona. 
residential subdivision. The city of Phoenix is located approximately in the center of the Salt River Project, which originally contained approximately 240,000 acres of irrigable land; as the city has expanded, the direct urbanization of these lands has progressed (Figure 1), so that almost one-half of the original Project lands have been converted. Table 1 Fig. I isi. shows the rate of urbanization in the area.

Total water diversions for urban and agricultural use have not changed appreciably through the shift in use. There is a saving in consumptive use, however, insofar as the municipal wastewater is effectively reused. Since. about 1960 the secondary treated wastewater from the Phoenix area has been discharged into the channel of the Salt River and has been utilized by the Buckeye Irrigation Company on farmlands a few miles downstream. This use peaked at about 40,000 acre-feet per year, or almost one-half of the gross requirement of the district, and a long-term contract has been implemented between the district and the city for a minimum firm supply of 30,000 acre-feet per year (Halpenny, 1973). Crops in that area include feed grains, sugar beets, cotton and alfalfa, for which the secondary effluent is not only satisfactory but additionally beneficial in terms of plant nutrient content.

Another portion of the Phoenix wastewater is being allocated to irrigation use in the Roosevelt Irrigation District, but in that instance it is receiving further treatment by filtration in order to reduce micro-organisms, since a large part of the crops grown in that district consists of truck vegetables. Even beyond these irrigation uses, a further allocation of wastewater will be made in future years to a proposed nuclear power plant west of Phoenix; a contract option on this has already been negotiated. 


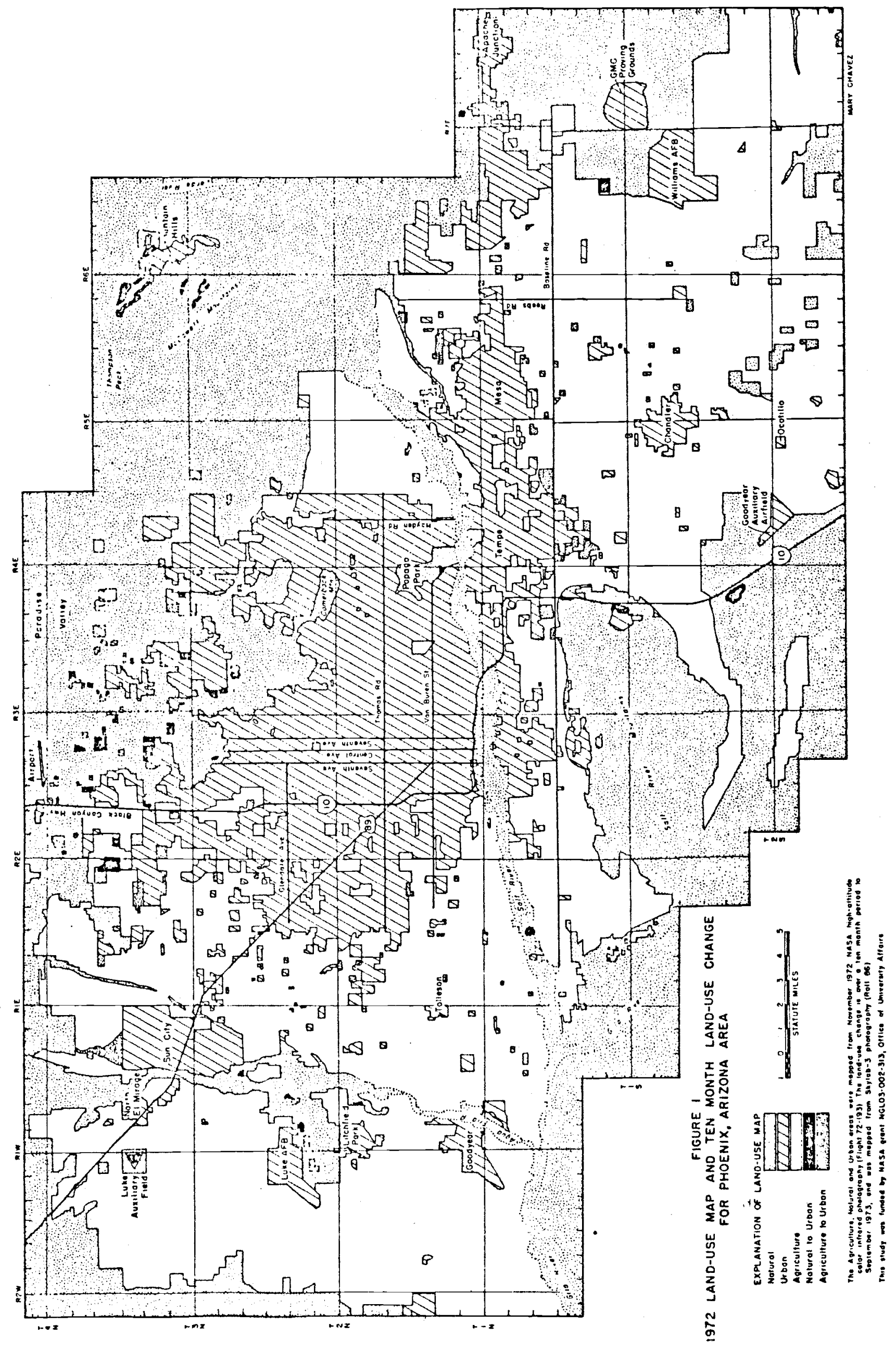


TABLE 1.-Rate of Urbanization in the Salt River Project, 1964-1973'

CROPLNHD
YEAR

$\begin{array}{lll}1964 & 69.97 & 30.03 \\ 1965 & 67.63 & 32.37 \\ 1966 & 66.85 & 33.15 \\ 1967 & 66.38 & 33.62 \\ 1968 & 65.76 & 34.24 \\ 1969 & 65.94 & 34.06 \\ 1970 & 63.77 & 36.23 \\ 1971 & 61.28 & 38.72 \\ 1972 & 58.22 & 41.78 \\ 1973 & 55.73 & 44.27\end{array}$

${ }^{1}$ The data were furnished by the Salt River Project.

${ }^{2}$ Total acreage of the Salt River Project on which these figures were based was 238,264 acres (964.22 million square meters)

${ }^{3}$ Slight deviation from the trend was caused by a close audit of the land status in 1969. 
These large-scale reuses of wastewater in the Phoenix region have permitted the conservation of corresponding quantities of primary water supplies.

This mode of direct shift in water use on the same lands has caused relatively few conflicts. One problem has been the operational task of delivering Project water to a very large number of points of use, as in residential subdivisions. Further; a long-range result is the permanent loss of thousands of acres of highly productive farmland to urbanization, in the face of an accelerating world food shortage.

\section{URBANIZATION AND WATER USE, TUCSON REGION}

In the Tucson region, the shift of water use from irrigation to municipal is occurring in a much different manner. Relatively little agricultural land has been converted directly to residential or commercial uses, since most of the irrigated lands are more remote from the urban area. These lands were relatively unaffected by municipal water production and use until the City of Tucson began to reach out and develop well fields in or near the farmlands for transport to the city. This occurred in two principal areas -- the Sahuarita area south of Tucson and the Avra Valley-Marana area to the west and north (Figure 2).

The City first acquired wellsites and pipeline rights-of-way during the 1950's in the Sahuarita area, the principal advantage being its upstream location which permits gravity flow northward into the City distribution system. The conflict which arose there was that the City wells and nearby irrigation wells were pumping from a common ground-water reservoir, and water-level declines were accelerated. This problem was compounded by development of the open-pit copper mining operations a few miles west of 


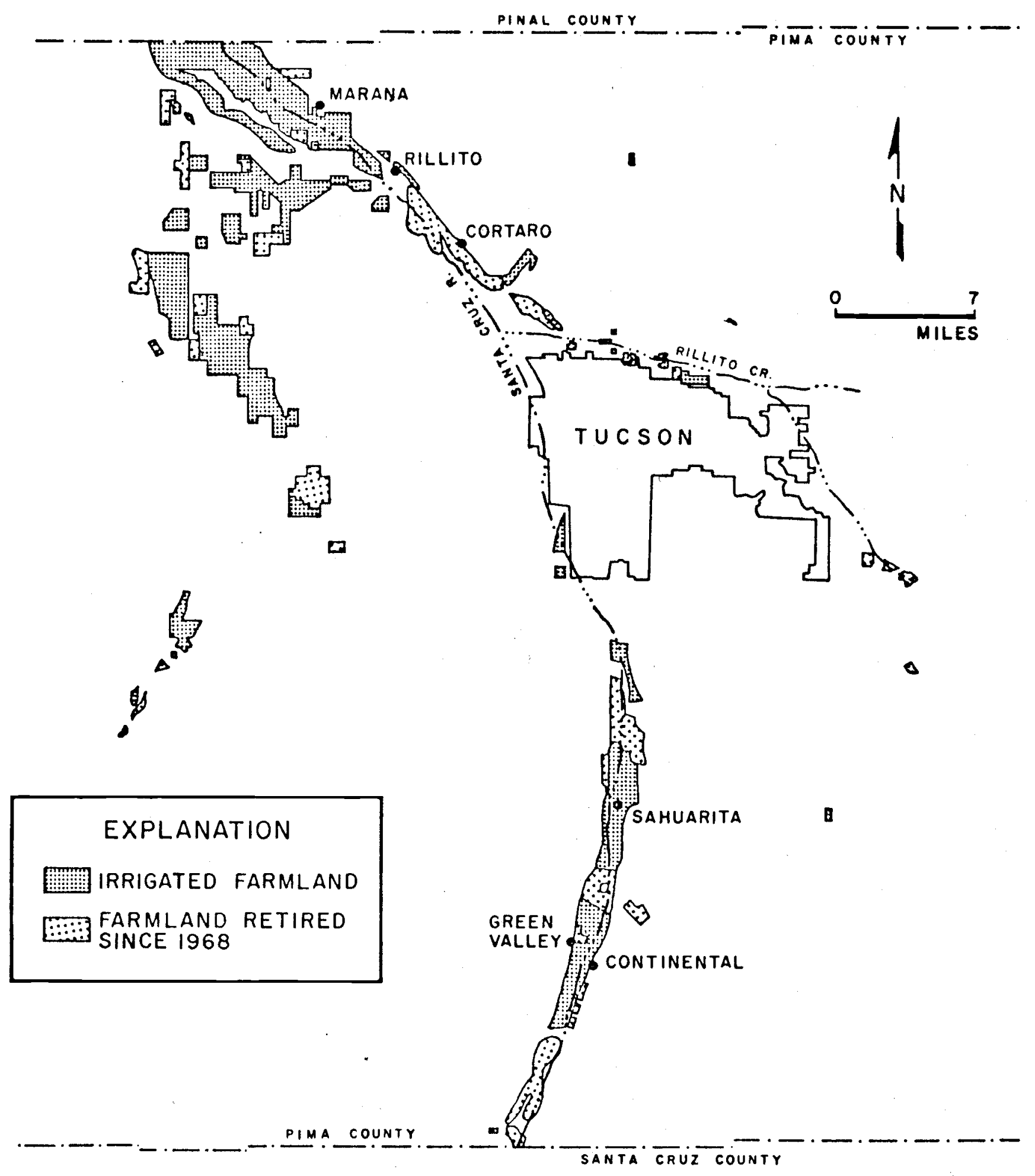

FIGURE $\chi$ - EFFECT OF URBANIZATION ON FARMLAND, TUCSON REGION, ARIZONA. 
this area; the mining companies procueded to acquire valley land for wellsites and are pumping heavily from the same aquifer. The farming interests brought suit against the mines in an attempt to limit their pumping, and the City of Tucson later intervened.

That lawsuit is approximately five years old at this writing, and has not yet reached resolution in court; however, some progress has been made by all parties toward a negotiated seltlement. The form of relief in the issue is the possibility of augmenting the ground-water supply with imported Colorado River water and/or treated municipal wastewater, in which the parties involved have expressed an active interest.

In the early 1960's the City of Tucson proceeded to develop a well field and pipeline in the southern part of Avra Valley (Figure 2), which is hydrologically separate from the Tucson Basin. Litigation arose there also, when the established farming interests successfully enjoined the city from pumping and transferring ground water from that "critical area" to another. (In Arizond a "Critical Groundwater Area" refers to "any groundwater basin or designated subdivision thereof, not having sufficient ground water to provide a reasonably safe supply for irrigation of the cultivated lands in the basin at the then current rates of withdrawal"). The court has allowed the City to pump from Avra Valley, however, to the extent that the City purchases fammland and retires it from irrigation. The City has proceeded to buy farm acreage for this purpose, and is utilizing the wells and pipeline for transfer of water to Tucson, although not at full capacity. More land purchases must be made if this system of farm retirement is to be pursued. Certain conflicts or problems have arisen from this procedure, however, as described below. 
Although not fully recognized by environmentalists, "controlled-growth" advocates or even local land planners, the forced retirement of farmland produces several undesirable effects. These need to be fully. identified and compared with the positive effect of acquiring more water for urian use. An environmental impact study is needed, although not required in Arizona, for implementation of such local planning policies. Most proposals of forced retirement have treated the question of "what to do with the retired familand" superficially (Jacobs, 1968) (Staff Report, 1974). In semi-arid areas with fragile desert ecosystems there are many problems inherent in reclanation of disturbed lands. The land will not revert to an esthetically pleasing desert growth without the considerable passage of time. The dominant species on disturbed land in desert areas of the southwest is tumbleweeds (Solsola kali). During the dry season these tumbleweed-covered areas are dusty. Wind-blown Lumbleweeds can destroy the esthetic appearance as well as change the ecology of land surrounding. the abandoned farms (Figure 3). Many animals such as rabbits, quail, doves and field mice, dependent upon the farmland for food, are forced to either move or die. Range grasses are established only with difficulty in this region of relatively low ammual rainfall (11 inches) and relatively iarge evapotranspiration rates. Additional water could be applied using the existing irrigation wells, but this would reduce the anount of water available for urban use. Hater-harvesting agrisystens could be used to concentrate the rainfall on to native grasses or agricultural crops (Cluff, 1974). These methods, allhough promisimg, are still in the small plot developmental stage. The idea has been advanced that the retired 
FLGURE 3.- CONDITION OF FAKMLAND RETLRLA BY THE CITY OF TUCSON FIVE YLARS AFTLK LAST' CRUP WAS PLANTED 
farmland could be converted to solar farms for the collection of energy; again, this techology has not been moven and needs additional development. The ideas advanced in the Staff Report of the City of Tucson (1974), suggest that the land can be traded, presumably to Federal agencies, for lands which are more desirable to the city. These new lands presumably would also be more esthetic and less difficult to manage. This would only transfer responsibility of reclamation of the retired farmland. Another proposed plan is to sell the land to developers for urbanization. This latter plan carries with it the implied but unstated requirement that. the city would support rezoning for high enough densities to make the development more profitable than on surrounding privately held lands.

This selected rezoning for urbanization of city-owned retired farmlands would be inequitable with regard to surrounding privately-owned lands, and would also create "urban sprawl". As is evident in Figure 2, the location of most of the farmland in castern Pima County is not adjacent to present municipal centers.

Most of the farmlands in Pima County are low-lying larids that are subject to flooding. If these lands are urbanized extensive channeling will be required. Some of the farms in the upper Santa Cruz Valley have served as overflow areas during severe flooding. These overflow areas have in the past not only reduced flood peaks downstream but also have served as valuable recharye areas. There are farming areas in Avra-llarana Valley that have also served as overflow-recharge areas. Urbanization and channelization of these areas would greatly reduce iatural recharge. Urbanization is also being suggested as a means of reclamation of llie large blocks of disturbed land now being used by the mining industry south of 
Tucson. It is related to the subject under discussion primarily because, if implemented, it would siphon off potential customers for the use of urbanized farmland. The City of Tucson has been trying through the State Legislature to change the groundwater laws. One contemplated change would allow them to buy the water rights without being required to purchase the land. Again, this would only shift the responsibility of what to do with the retired farmland back to the original owner.

The concept of forced retirement of farmlands as an alternative to water importation was conceived during the time of agricultural surpluses. However, at present, rapidly developing food shortages are causing conflict in this area and should not be overlooked by planners.

The 1973 cropping pattern of these lands is shown in Table 2. Miscellaneous orchard crops, pecans, and lettuce, comprising a total of 7600 acres, are directly consumed. Other crops such as alfalfa, grains and cotton have not been recognized as having significant food value. Table 3 indicates that even these crops have significant food impact. If needed, the entire acreage except orchards could be planted to wheat in any one year. High yielding wheat in Central Arizona can produce three tons of wheat per acre (Erie et al., 1973). At this production rate and using the protein and energy requirements of 600 pounds of wheat per person, the approximately 40,000 acres of remaining farmland in the Tucson region (eastern Pima County) could provide these food needs for 400,000 people (Food Nutrition Board, 1973).

Since most of the above described conflicts are not well known to the general public, there has not been much public opposition to farmland retirement. The farms that have been purchased were offered voluntarily by their owners for sale to the City and are located in relatively secluded areas. Adverse public opinion is to be anticipated as more land is retired 
TABLE 2.-Irrigated Land and Watur Use, Tucson Region, $1973^{1}$

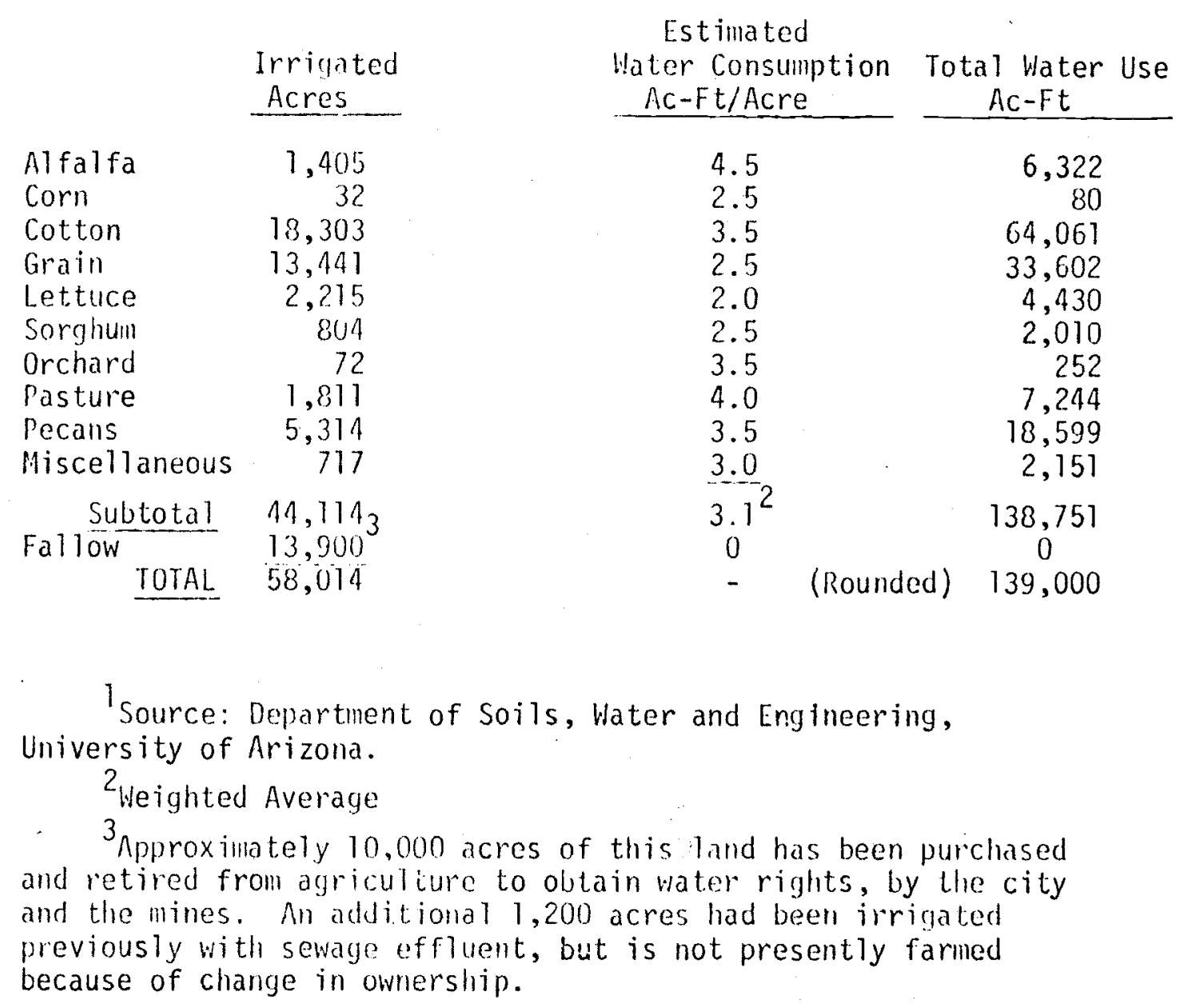




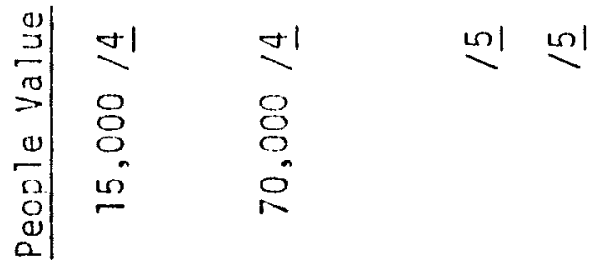

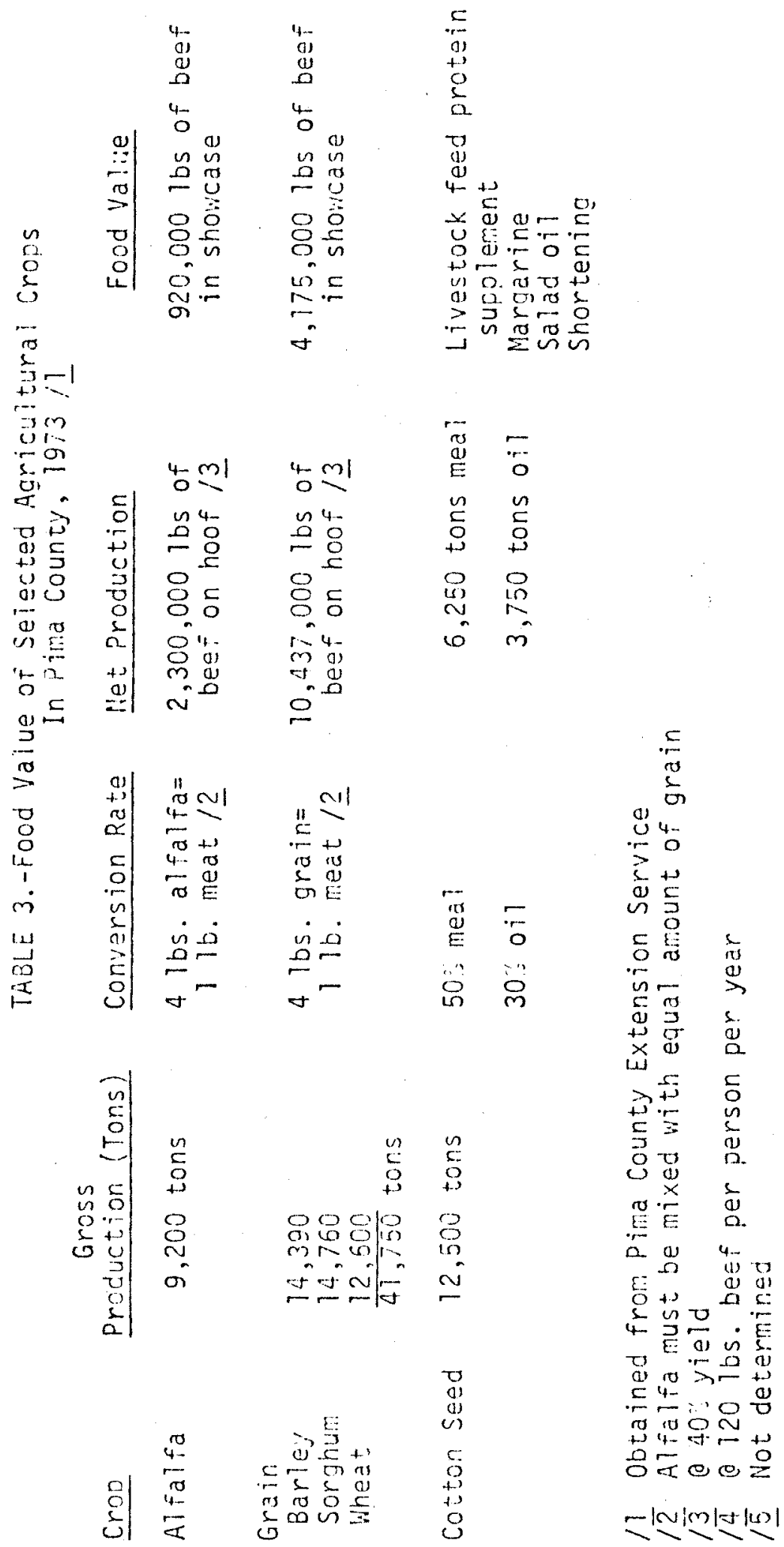


in more visible areas unless acceptable land reclamation and management procedures are developed. Because of rising farm market prices, there has been a growing reluctance recently for farmers to sell their land. Increased land costs and further adverse public reaction may be expected if the city is forced to acquire farmland through the exercise of eminent domain.

\section{EXCIIANGE OF MUNICIPAL WASTEWATER FOR IRRIGATION}

One method of reducing the acreage of farmland needed to be retired in the Tucson area would be to retain the cropland through irrigation with municipal waslewater. $\Lambda$ proposed exchange (Cluff et. al., 1971) whereby treated sewage effluent would be traded for groundwater now being used for irrigation, has been studied. Various methods of implementing the exchange have been proposed, ranging from individual contracts with farmers to municipal owmership (Cluff and DeCook, 1974).

City officials have been reluctant to enter into long term contracts with the farmers needed to pay for the distribution system, since they wish to retain control of the effluent. However, the option to purchase the farms at some time in the future to recover control of the effluent would still be open. The distribution system could then be extended to exchange with farmers for irrigation water now used in the Redrock area in Pinal County.

This type of arrangement would be easily initiated in the cortaroMarana Irrigation District. This district could immediately use up to approximately 22,500 acre-ieet during the off-lettuce season from April 15 to nugust 15. 
For the Avra Valley, which is not organized into an irrigation district, the most flexible plan from a water management point of view appears to be for the City to buy farms in a consolidated area and lease the land back to the farmers under a modified water delivery and cropping pattern. A schematic drawing of the Consolidated Irrigation District--Metropolitan Operated (CIDMO) is given in Fig. 4. By selecting an appropriate cropping pattern over 19,500 acres of irrigated land, the entire projected $1995 ; i$ ' ' effluent flow of 70,000 acre-feet could be efficiently utilized, provided an 8,000 acre-foot regulatory reservoir were available.

The alternative use for effluent being considered by the city-County Unit, the Metropolitan Utilities Management Agency, is use by the mines south of Tucson.

\section{SUMMARY REMARKS}

Continued transfer of water from agricultural to urivan use is inevitable if Arizona continues its present rate of urbanization. The Central Arizona Project and the reuse of municipal wastewater will reduce the total need for transfer, but will not eliminate it.

Direct conversion of farmland to urbanized areas, as is occurring in the Phoenix region, reduces the inherent conflict to the ultimate question of retaining sufficient farmland in cultivation to feed the populace.

Forced retirement of farmland as practiced in the Tucson area generates numerous types of conflicts, many of them related to the question of what to do with the retired land. This question has not been seriously studied, much less resolved; the issue indicates the need, not only for further research, but also for environmental inpact studies as a part of the planning process. 


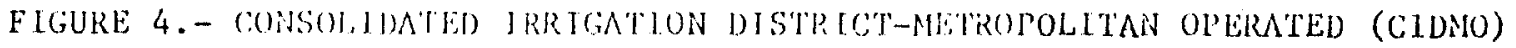
A SYSTLI FOR RUNLCLPAL WASTEINATER REUSE 


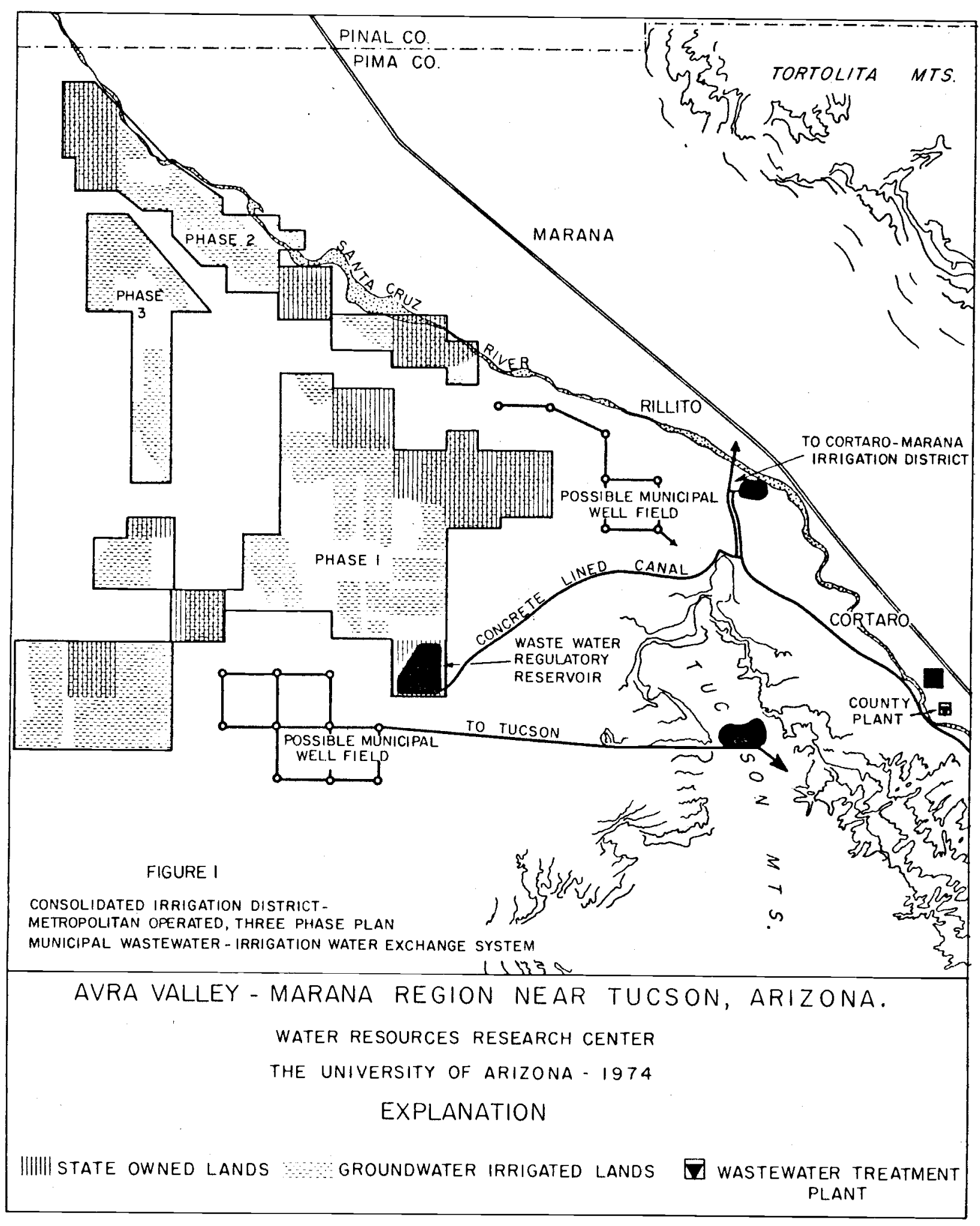




\section{ACKNOWLEDGMENTS}

The work represented herein was supported in part by the State of Arizona and in part by funds provided through the United States Department of the Interior, Office of Water Research and Technology, as authorized under the Water Resources Research Act of 1964 (P.L. 88-379).

\section{LITERATURE CITED}

Cluff, C. B. 1974. Engineering aspects of water harvesting research at The University of Arizona. Proceedings of the Water Harvesting Symposium, March 26-28, 1974. U.S. Water Conservation Laboratory, Phoenix, Arizona. Cluff, C. B. and K. J. DeCook. 1974. Metropolitan operated district for sewage effluent-irrigation water exchange. Hydrology and Water Resources in Arizona and the Southwest, Vol. 4, Arizona Section American Water Resources Assn. and the Hydrology Section of the Arizona Academy of Sciences, The University of Arizona, Tucson, Arizona.

Cluff, C. B., K. J. DeCook and W. G. Matlock. 1971. Technical and institutional aspects of sewage effluent-irrigation water exchange, Tucson region, Water Resources Bulletin, Vol. 7, No. 4.

Erie, L. J. , D. A. Bucks and 0. F. French. 1973, Consumptive Use and Irrigation Management for High-yielding wheats in Central Arizona", Progressive Agriculture in Arizona, Vol. 25, No. 2., pps. 14-15, March-Apri1, The University of Arizona, Tucson

Food Nutrition Board. 1973. Recommended dietary allowances. National Academy of Sciences-National Research Council.

Halpenny, L. C. 1973. Utilization of sewage effluent for agricultural purposes, Phoenix, Arizona. Paper presented at the 1973 Meeting of the American Society of Civil Engineers, Ft. Collins, Colorado. 


\section{LITERATURE CITED (cont.)}

Jacobs, J. J. 1968. An economic supply function for the diversion of irrigation water to Tucson. M.S. Thesis, Department of Agricultural Economics, The University of Arizona, Tucson, Arizona.

Staff Report. 1974. The Central Arizona Project. Metropolitan Utilities Management Agency Board, Pima County and City of Tucson. 